THE IMPACT OF GREAT MOM GREAT CHILDREN TRAINING TO IMPROVE YOUNG STREET MOTHER STIMULATION SKILL

Dessy Pranungsari ${ }^{\mathrm{a}}$, Nissa Tarnoto ${ }^{\mathrm{b}}$, Fatwa Tentama $^{\mathrm{c}}$

Psychology Departement, Ahmad Dahlan University, Yogyakarta, Indonesia.

dessyuad@gmail.com.,Nissa.tarnoto@psy.uad.ac.id.,fatwa.tentama@psy.uad.ac.id. 


\title{
THE IMPACT OF GREAT MOM GREAT CHILDREN TRAINING TO IMPROVE YOUNG STREET MOTHER STIMULATION SKILL
}

\begin{abstract}
The objective of this research is to examine the impact of "Great Mom Great Children" training to improve young street mother stimulation skill. The subjects of the research are from Yogyakarta. They are young homeless mothers who are commonly referred to as a street mother, young mothers who are less than 18 years old, mothers for unwanted pregnancy, mothers who have 0 to 5 years old children and mothers who are upbringing their children themselves. The experiment design used in this research is untreated control group design with dependent pretest and post-test sample. The data is collected by using Children Stimulation Skill Development Scale. The researchers perform Wilcoxon Test to examine the difference between stimulation skill level before and after the test. The result suggested that there was a significant difference before and after the treatment was given. It can be seen from $Z=-1,755$ and $p=0,079)$ (2-tailed)/0, 0395 (1-tailed) with $p<0.05$. Also, the result of Mann Whitney U-test showed that the average level of stimulation skill in experiment group participant was higher than that of control group participant with the result of pretestposttest $(p=0,074$ (2-tailed)/ $p=0.037$ (1-tailed) where $p<0.05$ which meant significant. In conclusion, "Great Mom Great Children" training is an effective method to improve children' stimulation skill for young street mothers.
\end{abstract}

Keywords: street children, stimulation skill

\section{Introduction}

Parents play an important role in their children language development (Papalia, Olds, and Feldman, 2008). Mother specifically is the closest figure to children. This then makes them the most reliable actor who can take care of their children. The success of children development relies heavily on the upbringing pattern when they are in their childhood. However, in fact, not all young mothers understand what the best nurture for their children would be, particularly on giving stimuli for children' development which can affect their later development.

Aisyah (2008) from various research result concludes that childhood development influences children later development and it can then increase their working productivity when they grow up. Thus giving maximum stimuli for children is beyond essential. In the education field, an early stimulus is very much needed to trigger stimulation for all development aspects. At this critical period, children require stimulation for their maximum potential development (Soetjiningsih, 2003). According to Monks, Knoers, dan Haditono (2004) the quality and quantity of upbringing pattern is closely related to stimulation giving.

The problem appears when mother assume that stimulation skill is a natural process and can automatically come in time. In fact, it basically is important for them to know about it in a further understanding. Parents' behavior regarding knowledge, attitude, and practice about simulation skill is crucial factor which must be possessed by them. It is because they can take care and educate their children in the best way possible (Arip, 2008).

The result of observation and interview with young mothers showed that the major problem faced by them is confusion in stimulating their children. Some of them worry about late development that may happen to their children. This condition gets even worse when they see other younger children have been able to walk and to do another thing. 
This problem can get more complex when this confusion happens to the young street mother who is below 18 years old. Many of them are not ready to raise a child due to unwanted pregnancy. The result of interview suggested that they are not aware and even careless about the importance of knowing every step of their children develop. It happens because they know nothing about how to stimulate and develop their children. They don't know in what age a child can talk, walk, play and socialize. It then results in the too late development of motoric, social and emotional ability.

Based on those reasons, the researchers believe that it is important to give the young street mother a psycho-education about stimulation skill. This is because training can increase their understanding in rising and stimulating their children so that it can provide positive impact towards their children' future development. A psycho-education can be training or non-training (Kode Etik Psikilogi, 2010). In this research, the researchers will give training. A study conducted by Pranungsari, Koentjoro, Kushartati (2014) suggested that the use of training is proven effective to decrease sexual, violent risk in the female teenager in a street children community. According to Utami (2004) training is a way of learning where individuals can increase their understanding and skill mastery.

The training given in this research is called "Great Mom Great Children." It consists of five sessions. Session one: the young mother will be trained to recognize and identify children development. Session two: explaining the importance of stimulation for children development. Session three: making recycle toys as educational tools. Session four: young mother becomes agent of change and session five: the practice of giving stimulation to their children.

This "Great Mom Great Children" training mainly focuses on utilizing things that can be easily found in their surroundings. For instance, the researcher uses recycle toys so that young street mother can use any object they can find around to stimulate their children. This is due to their economic background which can be categorized as the poor society. Thus, by using recycle toys, they would not spend so much money to buy stimulating toys. The toys used in this training are referred to as tools for educational purposes which have been proven able to increase children development (Tentama, et al., 2015).

According to the research background, the researchers believe that it is necessary to research to know the impact of Great Mom Great Children training in improving simulation skills for young street mothers.

\section{Method}

\section{Participant}

The subjects of this research are the young street mother who lives in some areas in Yogyakarta. Subjects are street children who earn money by singing along the road Malioboro, and north square Yogyakarta They consist of sixteen subjects which fall into two groups. Eight subjects are grouped as experiment group and the other eight acts as the control group with the following characteristics:

1. Young homeless mother who lives in Yogyakarta

2. Young mother aged below 18 years old

3. Mother of unwanted pregnancy

4. Mother who have 0-5 years old children

5. The mother who takes care of their baby themselves.

\section{Instrument}

The measurement tools used in this research is Children Stimulation Skill Development Scale. This stimulation skill scale is designed based on the code of stimulation, detection and 
early intervention of children development in early health service (Departemen Kesehatan, 2006). The scale is filled by participants accompanied by the researcher. This scale is also based on good stimulation characteristics which can be seen as follows:

1. Stimulation is conducted based on the value of love and compassion.

2. Exemplifying children on how to behave well because they will always imitate their closest person

3. Give stimulation according to their age

4. Provide various stimulis by inviting children to play and sing at free will. Avoid force and punishment.

5. Stimulate step by step and continuous according to their age and four basic children skills

6. Use helping tools or simple game which is saved and easily found in their surroundings

7. Give equal chances to boys and girls

8. Give necessary rewards upon their achievement

\section{Validity and Reliability of Measuring Instrument}

The items on the scale are filled up and selected according to correlation coefficient criteria which have been corrected $\left(\mathrm{r}_{\mathrm{xy}}\right)$. Children Stimulation Skill Development Scale uses 0,25 lowest point so that items which have gap index higher or equal to 0,25 is eligible to be included in the research scale. The result of the test analysis towards 32 items of the scale based on alpha $(\alpha)$, suggested that reliability coefficient alpha is 0,933 with the gap index items $\left(r_{i t}\right.$ increase from 0,319 to 0,864 . The valid and reliable items are 32 which will then be used for this research.

\section{Research Design}

The experiment design used in this research is experiment quasi. This experiment uses less strict control towards extra variable, and the sample is not taken randomly. It is done because pure experiment design would not be possible to be performed (Myers, 2002). The researchers perform Untreated Control Group Design with Dependent Pretest and Posttest Samples which uses experiment group and control group. They are given pretest and posttest (Shadish \& Cook, 2002).

\begin{tabular}{|ccrr|}
\hline $\mathrm{NR}$ & $\mathrm{O}_{1}$ & $\mathrm{X}$ & $\mathrm{O}_{2}$ \\
$\overline{\mathrm{NR}}$ & $-\mathrm{O}_{1}$ & & $\mathrm{O}_{2}$
\end{tabular}

Figure 1. Experiment Design

Note:

$\mathrm{NR}=$ Non-Random

$\mathrm{O}_{1} \quad=$ Pretest

$\mathrm{X}=$ Training

$\mathrm{O}_{2} \quad=$ Posttest

\section{Research Instrument and Tools}

Tools and materials used in this research are as follow: 
1. Informed consent which contains agreement to participate in this research

2. Children Stimulation Skill Development Scale (SKSPA)

3. Training Module "Great Mom Great Children"

4. Training worksheet: evaluation worksheet, observation worksheet, and participation worksheet

5. Classroom or place to held the training

6. Audio visual equipment such as laptop, speaker, LCD, microphone,

7. Recycled bottle, magazine, newspaper, box, woods, etc.

8. Pencil/pen, scissors, and glue)

9. Camera

\section{Experiment Procedure}

This research is run in three steps:

1. Preparation Step

a. The researchers conducted an early study to understand and identify the problems faced by the young street mother. The researchers found that they have to raise a baby at such a young age and yet they were not emotionally stable.

b. The researchers conducted literature study by analyzing journals and other scientific papers which were related to stimulation skills.

c. The researchers maintained cooperation with Do More foundation to get data and detailed information about the subject.

d. After studying some literature, the researchers arranged a module for training which has been adjusted to the characteristics of the research subject. The module used an interactive method by involving audio visual or kinesthetic activity.

e. The researchers designed measurement scale according to the literature after which professional judgment and test were performed.

f. The researchers grouped the subject and placed the young street mother aged below 18 years old in one group (Subjects are between 14 to 22 years old)

Choosing supporting team

g. Supporting team in this research was research assistant from Do More Foundation. Their duty was to help the research process from preparation to practice. Also, they also helped giving Children Stimulation Skill Development Scale both pretest and posttest. A team from Do More Foundation helped the researchers maintain good communication with young street mother, collect personal background of the research subjects and conduct training so that the researchers can know more deeply the problem they are facing.

2. The Research Steps

a. The researchers and research assistant distributed informed consent to experiment group and control group. This consent dealt with the availability and willingness to participate as the research subject. The experiment group was also informed about the research schedule so that they can participate actively.

b. The experiment and control group were all asked to complete Children Stimulation Skill Development Scale as a pretest before training was given.

c. Coordination and module simulation were performed to ensure the research was ready.

d. "Great Mom Great Children" Training Process

This training was divided into five sessions. Session one: recognizing and understanding children development. Session two: knowing the importance of stimulation for children development, session 3: making recycle toys for educational purposes, session 4: the 
mother can become the agent of change, session 5: a practice of giving stimulation to children. Training "Great mom Great Children" was conducted over two days one night.

\section{Data Analysis}

The researchers use non-parametric statistics Mann-Whitney U-test to analyze the data. This analysis is used to figure out the stimulation skill difference between experiment group and control group after the treatment is given. Besides, Wilcoxon test is also used to test and examine the stimulation skill level before and after the treatment is given to know the gap significance from pretest to posttest. Researchers use on-parametrical analysis because the research data is not normally distributed. The data analysis is conducted by using SPSS 17.0 for windows.

\section{RESULT}

The result of Wilcoxon test showed that $\mathrm{Z}=-1,755$ and $\mathrm{p}=0,079)$ (2-tailed)/ 0, 0395(1tailed) with $\mathrm{p}<0.05$. It meant that there was a significant difference regarding stimulation skill in the young street mother before (pretest) and after (posttest) the treatment was given. The average level of stimulation skills after the training was higher than before the training was given. In addition to this, the result of homogeneity test suggested that Levene statistic = 1,910 and sig $=0,189(\mathrm{p}>0,05)$. Thus, it can be said that variance is homogeny.

Table. 1

The result of Mann-Whitney $U$ Test

\begin{tabular}{lll}
\hline Data & $\mathbf{Z}$ & $\mathbf{P}$ \\
\hline Pretest- & - & $\mathrm{p}=0,074$ (2-tailed) \\
postest & 1,789 & $\mathrm{p}=0.037$ (1-tailed) \\
\hline
\end{tabular}

We can conclude from the table that in general, the difference regarding stimulation skill level in young street mother between experiment group who is given the training and control group who isn't is significant. The average level of stimulation skill in experiment group is significantly higher than that of the control group. It can be further seen from Pretest-posttest $(p=0,074(2$-tailed $) / p=0.037$ (1-tailed) where $\mathrm{p}<0.05$ which meant significant.

\section{Discussion}

This research aims to know the effectiveness of "Great Mom Great Children" training in increasing stimulation skills for the young street mother. The result of Wilcoxon test suggested that there was a difference in their stimulation skill before and after the training. The average level of stimulation skill after training is significantly higher than before the training. Furthermore, Mann Whitney U-test has given stronger proof that the skill in experiment group was once again higher than that of the control group. It can be a significant proof that the difference is caused by the training. It shows that "Great Mom Great Children" training is an effective method to improve young street mother stimulation skill.

This research than opposes the assumption that stimulation skill cannot come automatically in time, but rather it must be trained specifically to the young mother as the closest figure to children. Skill is closely related to willingness to do something easily and correctly (Iverson, 2001). Skill can be related to behavior. Whereas behavior is based on 
someone's attitude towards the particular object. Attitude has three main components. They are cognitive, affective and conative (Baron \& Byrne, 2005). Besides, parents play a crucial role in developing their children so that it is necessary for them to be trained. This assumption is also believed by Walker, Chang, Powellm Simonoff and Grantham (2007). If there is something wrong with children emotional development and other psychological aspects, it can be the cause of their quality of life, environment and upbringing pattern. McFarlane, Dodge, Burrel, Crown, Cheng, and Duggan (2010) also stated that family psychosocial function has the impact to parent upbringing pattern and children behavior. A young mother from street community possesses higher risk in facing the problem, and thus it is important for them to be given parenting training to minimalize wrong practice when they take care of their children.

"Great Mom Great Children" training is designed by considering every important step to educate and create a good behavior. Positive attitude in this training involves giving cognitive aspects where the participant is given knowledge about the importance of stimulation and the impact that may appear if children are not stimulated early and correctly. This then can create late development. Thus, there will be insight and understanding about this important knowledge in giving early stimulation to children.

Regarding affective side, the participant will realize and be able to trigger good feeling in stimulating their children without force. Walker, Chang, Powell, Grantham, and Sally (2005) also stated that if early education and stimulation are not present, it impacts children cognitive development in their adulthood. It can be avoided by giving an early stimulation.

After good attitude is established, the researchers urge the parent to stimulate their children by practicing the knowledge they have learned in real life. Thus there will be a process where the participant can understand and implement the knowledge in their daily life. It supports Utami's opinion (2004) in saying that training is a way of learning where individuals can increase their understanding and skill mastery. In this case, "Great Mom Great Children" training has been proven effective to increase parent stimulation skill. Furthermore, this training is designed according to the characteristics of the participant who comes from the street community and have limited understanding. Active learning is also inserted in this training where participants are stimulated to be active in every step such as discussion, reflection and role play.

This training involves many learning styles including audiovisual ( the short movie about the impact that happens when children are not stimulated), kinesthetic where the participant is encouraged to do the outdoor activity and role play. The purpose of role play is to avoid monotonous class which may result to boring activity. This is because of the researchers aware of the advantages of using active learning. Encouraging students to actively participate in the classroom will make them active (Prince, 2004). This same strategy performed in education has allowed the student to have the longer memory about the learning material (Cherney, 2008). Furthermore, students are becoming more confident and actively participate in the learning process (Rucket, Plack \& Maring, 2014). A part from the ability to see participant characteristics, this training is also designed by considering participant background. They mainly are unable economically, and thus they are encouraged to use cheap and accessible toys to stimulate their children. It is not necessary for them to buy expensive toys.

The researchers know that this research is only an early step and therefore there must be additional action to guide and help the young street mother to raise their children. The challenge in giving stimulation will become bigger when their children get older. Thus giving the best help is important to help them raise their children well. 


\section{Conclusion}

The researchers conclude that "Great Mom Great Children" training is an effective way of improving young street mother stimulation skills.

\section{REFERENCES}

Aisyah, S. (2008). Perkembangan dan konsep dasar pengembangan anak usia dini. Jakarta: Universitas Terbuka.

Arip, M. (2008). Pengaruh metode penyuluhan terhadap perilaku ibu dalam stimulasi bermain sesuai perkembangan kognitif anak usia 4-6 tahun. http://digilib.litbang.depkes.go.id/go.php?id=jkpkbppk-gdl-res-2008moharip$2489 \&$ node $=146 \&$ start $=406$.

Azwar, S. (1994). Seleksi aitem dalam penyusunan skala psikologi. Buletin Psikologi, 2, 2633.

Azwar, S. (2004). Dasar-dasar psikometri. Edisi 1. Yogyakarta: Pustaka pelajar.

Azwar, S. (2005). Penyusunan skala psikologi. Edisi 1. Yogyakarta: Pustaka pelajar.

Azwar, S. (2006). Reliabilitas dan validitas. Edisi 3. Yogyakarta: Pustaka pelajar.

Baron, R. A \& Byrne, D. (2005). Psikologi sosial. Edisi 10. Jakarta: Erlangga.

Catron, C. E \& Allen, J. (1999). Early childhood curriculum A creativity play model. New Jersey: Prentice Hall.

Cherney, I. D. (2008). The effects of active learning on students' memories for course content. Active Learning in Higher Education, 9(2),152-171.

Departemen Kesehatan, Direktorat Jenderal Pembinaan Kesehatan Masyarakat. (2006). Pedoman pelaksanaan stimulasi, deteksi dan intervensi dini tumbuh kembang anak ditingkat pelayanan kesehatan dasar. Jakarta: Depkes.

Iverson. (2001). Memahami ketrampilan pribadi. Bandung: CV. Pustaka

McFarlane, E., Dodge, R., Burrel, L., Crown, S., Cheng, T. L \& Duggan, A. (2010). The Importance of Early Parenting in At -Risk Families and Children's Social-Emotional Adaptation to School. Academic Pediatric Association, 10(5), Pg 330.

Monks, F. J., Knoers, A. M. P \& Haditono, S. R. (2004). Psikologi perkembangan pengantanungsarir dalam berbagai bagiannya. Yogyakarta: Gadjah Mada University Press.

Myers, A. \& Hansen, C.H. 2002. Experimental Psychology. $5^{\text {th }}$.Ed. Pacific Grove, CA: Wordsworth. 
Papalia, D. E., Olds, S. W., Feldman, R. D. (2008). Human development (psikologi perkembangan). Jakarta: Kencana.

Pranungsari, D., Koentjoro \& Kushartati, S. (2014). Psychoeducation of healthy dating to reduce the risk of sexual violence in female street children, Journal of Educational, Health and Community Psychology 3(3), 42-54.

Prince, M. (2004). Does active learning work? A review of the research. Journal of Engineering Education, 93(3), 223-231.

Rucket, E., Plack, M. M \& Maring, J. (2014). A Model For Designing a Geriatric Physical Therapy Course Grounded in Educational Principles and Active Learning Strategies. Journal of Physical Therapy Education, 28(2),1-17.

Shadish, W. R \& Cook, T. D. (2002). Experimental and quasi-experimental design for generalized causal inference. Boston: Houghton Mifflin Company.

Soetjiningsih. (2003). Tumbuh kembang anak. Jakarta: EGC.

Tentama, F., Tarnoto, N \& Pranungsari, D. (2015). Pengaruh metode pelatihan stimulasi untuk meningkatkan perkembangan anak usia dini (Studi Eksperimen Pada Anak dan Ibu Muda Jalanan). Laporan Penelitian. Yogyakarta: Kopertis Wilayah V.

Utami, R. R. (2004). Efektivitas pelatihan untuk meningkatkan keterampilan sosial pada anak sekolah dasar kelas 5. Tesis. Yogyakarta: Fakultas Psikologi Universitas Gadjah Mada.

Walker, S. P., Chang. S. M., Powell. C. A., Grantham. S. M., Sally. (2005). Effects of Early Childhood Psychosocial Stimulation and Nutritional Supplementation on Cognition and Education Growth-Stuned Jamaican Children: Prospective Cohort Study. Proquest Nursing \& Allied Health Source, 366, 1804-07. DOI: 10.1016/S0140-6736 (05).

Walker, S. P., Chang. S. M., Powell. C. A., Simonoff, E \& Grantham. S. M. (2007). Early Childhood Stunting Is Associated With Poor Psychological Functioning in Late Adolescence and Effects Are Reduced by Psychosocial Stimulation. The Journal of Nutrition, 137(11), pg 2464. 